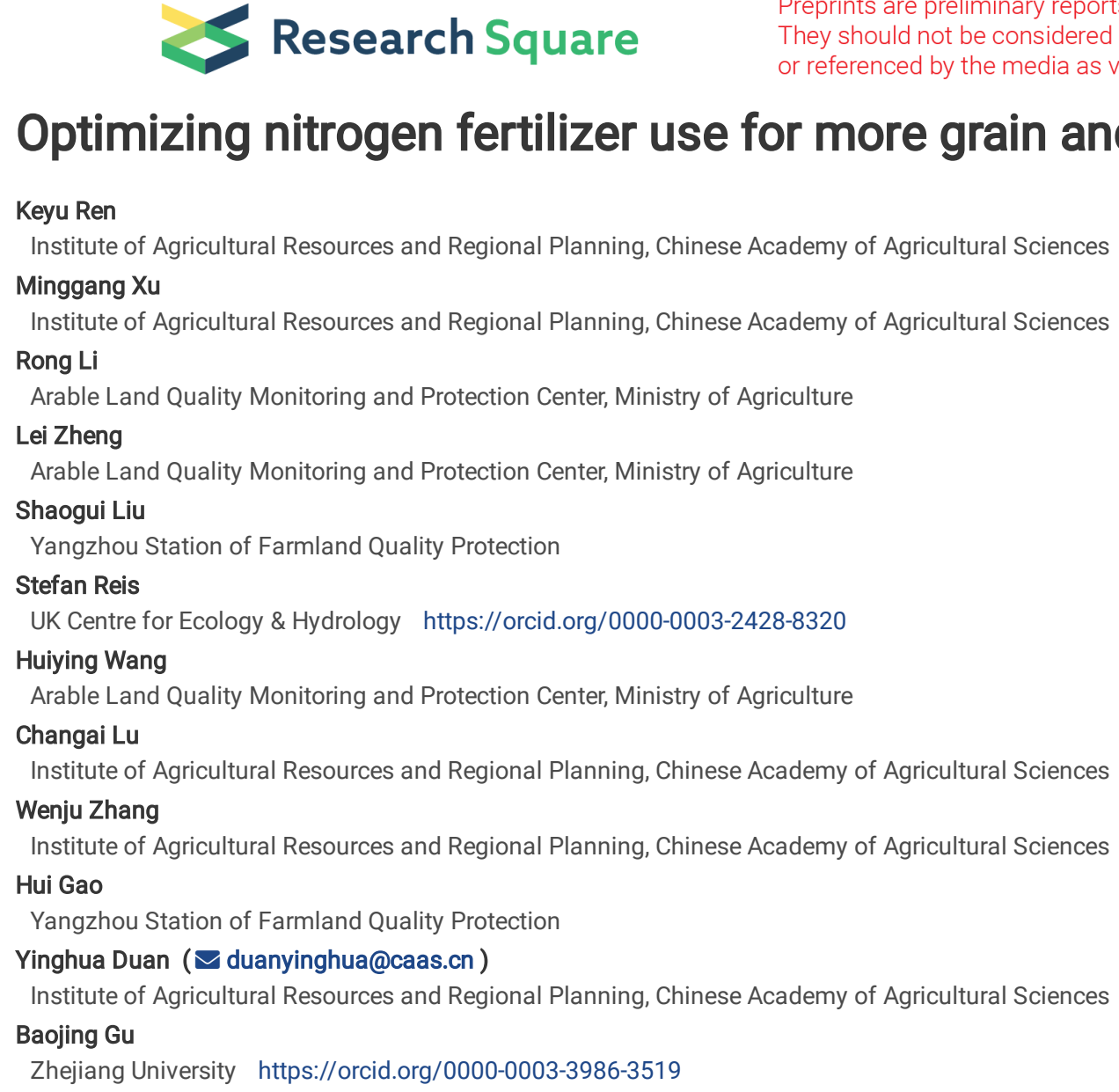

\section{Keyu Ren}

Institute of Agricultural Resources and Regional Planning, Chinese Academy of Agricultural Sciences

Minggang $\mathrm{Xu}$

Institute of Agricultural Resources and Regional Planning, Chinese Academy of Agricultural Sciences

Rong Li

Arable Land Quality Monitoring and Protection Center, Ministry of Agriculture

Lei Zheng

Arable Land Quality Monitoring and Protection Center, Ministry of Agriculture

Shaogui Liu

Yangzhou Station of Farmland Quality Protection

Stefan Reis

UK Centre for Ecology \& Hydrology https://orcid.org/0000-0003-2428-8320

\section{Huiying Wang}

Arable Land Quality Monitoring and Protection Center, Ministry of Agriculture

\section{Changai Lu}

Institute of Agricultural Resources and Regional Planning, Chinese Academy of Agricultural Sciences

Wenju Zhang

Institute of Agricultural Resources and Regional Planning, Chinese Academy of Agricultural Sciences

Hui Gao

Yangzhou Station of Farmland Quality Protection

Yinghua Duan ( $\nabla$ duanyinghua@caas.cn )

Institute of Agricultural Resources and Regional Planning, Chinese Academy of Agricultural Sciences

Baojing Gu

Zhejiang University https://orcid.org/0000-0003-3986-3519

\title{
Optimizing nitrogen fertilizer use for more grain and less pollution
}

\section{Article}

Keywords: optimal nitrogen $(\mathrm{N})$ management, crop production, fertilizer

Posted Date: April 7th, 2021

DOI: https://doi.org/10.21203/rs.3.rs-361734/v1

License: (9) (7) This work is licensed under a Creative Commons Attribution 4.0 International License. Read Full License 


\section{Abstract}

Optimal nitrogen $(\mathrm{N})$ management is critical for efficient crop production and agricultural pollution control. However, it is difficult to implement advanced management practices on smallholder farms due to a lack of knowledge and technology. Here, using 35,502 on-farm fertilization experiments, we demonstrated that smallholders in China could produce more grain with less $\mathrm{N}$ fertilizer use through optimizing $\mathrm{N}$ application rate. The yields of wheat, maize and rice were shown to increase between $10 \%$ and $19 \%$ while $\mathrm{N}$ application rates were reduced by $15-19 \%$. These changes resulted in an increase in $\mathrm{N}$ use efficiency (NUE) by $32-46 \%$ and a reduction in $\mathrm{N}$ surplus by $40 \%$ without actually changing farmers' operational practices. By reducing $\mathrm{N}$ application rates in line with official recommendations would not only save fertilizer cost while increasing crop yield, but at the same time reduce environmental $\mathrm{N}$ pollution in China. However, making progress towards further optimizing $\mathrm{N}$ fertilizer use to produce more grain with less pollution would require managements to improve farmers' practices which was estimated to cost about 11.8 billion US dollars to implement.

\section{Introduction}

Producing more food with less pollution is a grand challenge, which is crucial for global sustainable development goals (SDGs) ${ }^{1,2,3}$. With growth and increasing affluence of the global population, the amount of food needed is continually increasing, and a large share of the global population is still suffering from malnutrition, especially in developing economies ${ }^{4}$. Smallholder farming is the prevalent form of agricultural production in these developing economies, satisfying about $40 \%$ of global food demand ${ }^{5}$. However, misuse and overuse of fertilizers often occur on smallholder farms, leading to not only a lower crop yield, but also damages to the environment and human health ${ }^{6}$. Agricultural non-point-source pollution has become a dominant contributor to local environmental pressures in many regions of the world. To address these challenges, many best management practices and concepts such as soil testing and 4R stewardship have been developed ${ }^{7,8}$, however, they are rarely implemented on smallholder farms due to a lack of knowledge and technological facilities ${ }^{9}$.

China is the most populous country in the world. It feeds $18 \%$ of global population with only $9 \%$ of global cropland area, but is using about $30 \%$ of the global synthetic fertilizer production ${ }^{10,11}$. Overuse of fertilizers has led to substantial damages to environmental quality and human health, including eutrophication, air pollution, soil acidification, biodiversity loss and greenhouse gas emission ${ }^{12,13,14}$, with very high remedial costs. Chinese governments have, for instance, invested over 45 billion US dollars to control the eutrophication of Lake Tai during the past decade ${ }^{15}$. However, using too much fertilizer in many areas, a large yield gap is still found in China's smallholder agriculture ${ }^{16}$. Soil testing and other advanced agricultural management practices have been proposed to improve agricultural performance. However, the small farm size ( $<0.5$ hectare per household) and low agricultural income share $(<20 \%)$ inhibit the implementation of such advanced management practices which normally require changes agricultural operational practices ${ }^{17}$. Large-scale farms typically do not have the same constraints as smallholders and can invest more in knowledge and technology, and are therefore higher $\mathrm{N}$ use efficiency ${ }^{6,18}$. Therefore, in order to progress the development of large-scale farming, it is crucial to first investigate how to introduce improvements of agricultural management practices.

In this paper we quantify the relationship between $\mathrm{N}$ application rate and crop yield across China, based on data from 35,502 on-farm fertilization experiments conducted over a period from 2005 to 2015 (Fig. 1), This assessment has a focus on farmers' practices at national scale and the following key objectives: 1) to quantify the optimal $\mathrm{N}$ application rate and related crop yield, $\mathrm{N}$ use efficiency (NUE) and $\mathrm{N}$ surplus in different regions of China; 2) to estimate the reduction potential of $\mathrm{N}$ fertilizer use and how this contributes to crop yield and $\mathrm{N}$ loss reduction, without changing farmers' practices; 3 ) to estimate the economic input and benefits of further optimizing farm management practices.

\section{Results And Discussion}

\section{Optimal N rate}

Crop yield typically increases with $\mathrm{N}$ fertilizer application until a maximum yield level is reached. Beyond this point, a further increase of $\mathrm{N}$ application rate will

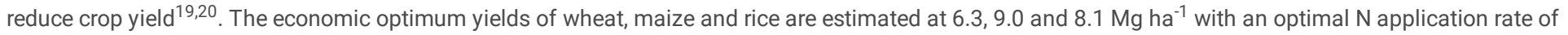
178,184 and $170 \mathrm{~kg} \mathrm{~N} \mathrm{ha}^{-1}$, respectively (Fig. 2). The optimal $\mathrm{N}$ application rate can achieve the target yield with little damage to economic profits for farmers $^{21,22}$. Under an optimal $\mathrm{N}$ rate, the NUE can be as high as $72 \%, 60 \%$ and $73 \%$, and the $\mathrm{N}$ surplus 67,96 and $65 \mathrm{~kg} \mathrm{~N}^{-1} \mathrm{for}$ wheat, maize and rice, respectively (Fig. 2). With the exception of maize, the $\mathrm{N}$ surplus is much smaller than the threshold of $\mathrm{N}$ residual in soil derived from the Nitrates Directive $\mathrm{C}^{23}$ (80 $\mathrm{kg} \mathrm{ha}^{-1}$ ). Optimizing $\mathrm{N}$ application rate alone can achieve a good performance of crop production using farmers' practices.

Substantial variations of the optimal $\mathrm{N}$ application rate and crop yield are found across China ${ }^{22,24}$. Generally, higher optimal $\mathrm{N}$ application rates are found in regions with better natural conditions such as high soil fertility and favourable climate, including the North China Plain (NCP) and the Middle-Lower Yangtze Plain (MLYP). Such areas with higher N application rates lead to higher crop yields in these regions, as well as result in a higher NUE and lower $\mathrm{N}$ surplus. Relatively lower optimal $\mathrm{N}$ application rate and related yields are found in other regions e.g. across Western China, primarily due to lower soil quality and less favourable climate 25,26 .

Although a higher yield is found for maize compared to wheat and rice, it has the lowest NUE, and the largest $\mathrm{N}$ surplus, with $\mathrm{N}$ surplus $>80 \mathrm{~kg} \mathrm{~N}$ ha-1 commonly found for maize production in many regions in China (Fig. 3). Some hotspot areas of high $\mathrm{N}$ application rates, yield, NUE and $\mathrm{N}$ surplus are found scattered across many regions, illustrating the existence of substantial variations of agricultural management at local scale. Meanwhile, NUE above $90 \%$ and $\mathrm{N}$ surplus below $0 \mathrm{~kg} \mathrm{~N} \mathrm{ha}^{-1}$ are also found in some regions, suggesting that soil $\mathrm{N}$ mining occurs in these regions, despite a prevalence of excess $\mathrm{N}$ fertilizer use (Fig. 3).

\section{Mitigation potential}


Compared to farmers' conventional $\mathrm{N}$ application rate, strategies aiming to optimize $\mathrm{N}$ application can not only lead to a reduction in the application rate of $\mathrm{N}$ fertilizers, but also improve crop yield and NUE without changing farmers' practices. The yields of wheat, maize and rice can be increased by $10 \%, 19 \%$ and $13 \%$ with an optimal $\mathrm{N}$ application rate reduced by $15 \%, 16 \%$ and $19 \%$, respectively. Under such an optimal N rate, NUE can increase by $32 \%, 46 \%$ and $40 \%$, and N surplus decline by $39 \%, 36 \%$ and $48 \%$, respectively (Fig. 4 and Supplementary Table 1).

By optimizing the $\mathrm{N}$ application rate, fertilizer cost savings for wheat, maize and rice production of $0.5,1.0$ and 0.8 billion US dollars, and increase grain income by 2.4, 9.1 and 5.8 billion US dollars, respectively could be achieved. From an environmental protection point of view, the overall $\mathrm{N}$ surplus of croplands would be reduced by $5.1 \mathrm{TgN}$ (Fig. 5 and Supplementary Table 2). Such a reduction in the $\mathrm{N}$ application rate based on official recommendations would not only achieve fertilizer cost savings and increase crop yield, but also have substantial environmental benefits in China.

\section{Better management}

Beyond optimizing $\mathrm{N}$ application rates by modifying farmers' operational practices, further adjustments to management are required as solely achieving an optimal $\mathrm{N}$ application rate is only a partial solution to the overall problem. The relationships between $\mathrm{N}$ input and $\mathrm{N}$ output (harvested $\mathrm{N}$ ) of the three main crops of China under the optimal $\mathrm{N}$ rate are compared with the minimum productivity level ( $\mathrm{N}$ output $=80 \mathrm{~kg} \mathrm{ha}^{-1}$ ) and ranges for NUE $(50 \%-90 \%)$ that suggested by the EU Nitrogen Expert Panel ${ }^{27}$ (Fig. 3). Nitrogen use efficiency can reach $50-90 \%$ in $67 \%$ of wheat producing regions, $54 \%$ of maize producing regions and $74 \%$ of rice producing regions respectively, of which $40 \%, 30 \%$ and $46 \%$ can achieve $\mathrm{N}$ surplus less than $80 \mathrm{~kg} \mathrm{ha}^{-1}$ (Fig. 3 ). However, $54-70 \%$ of the regions producing these three crops have the risks of soil $\mathrm{N}$ mining, $\mathrm{N}$ pollution and food insecurity with the reasons of insufficient nutrient supplement, volatilization of urea, and improper management. It means that further adjustments to fertilization regimes are required to avoid the risks.

For regions where a risk of soil $\mathrm{N}$ depletion is indicated (NUE > 90\%), maintaining soil fertility through manure application is required ${ }^{28,29}$, with an associated estimated annual cost of $0.9,0.7$ and 0.9 billion US dollars for wheat, maize and rice, respectively (Fig. 5 and Supplementary Table 3 ). In contrast, in regions where NUE can reach $50-90 \%$ while $\mathrm{N}$ surplus exceeds $80 \mathrm{~kg} \mathrm{ha}^{-1}$, this indicates that $\mathrm{N}$ input exceeds $\mathrm{N}$ demand of crops and hence substantial $\mathrm{N}$ loss occurs. Here, $\mathrm{N}$ inputs and losses need to be reduced by applying slow-release $\mathrm{N}$ fertilizers ${ }^{30,31}$ which incur additional costs of $0.3,0.4$ and 0.3 billion US dollars for wheat, maize and rice, respectively (Fig. 5 and Supplementary Table 4).

Even when achieving an optimal $\mathrm{N}$ rate, there are still many regions where NUE remains below $50 \%$, especially for maize ( $31 \%$ ). In these areas crop yield per unit area can only be increased and the application of $\mathrm{N}$ fertilizer reduced by reasonably increasing planting density and at the same time applying slowrelease $\mathrm{N}$ fertilizers ${ }^{31,32}$, at an additional cost of $0.2,0.7$ and 0.1 billion US dollars for wheat, maize and rice, respectively (Fig. 5 and Supplementary Table 5). Regions with an average $\mathrm{N}$ output below $80 \mathrm{~kg} \mathrm{ha}^{-1}$ food security concerns are most prominent, which mostly occurs in the Western China (Fig. 1). Such areas with the problems of inadequate farmland infrastructure (e.g. barren land, sloping land, saline-alkali land and no irrigation facilities) ${ }^{33,34,35}$. Based on the results of high standard farmland construction project in China ${ }^{36}$, we need to additional cast 7.3 billion US dollars (wheat: 2.3 , maize: 4.7 , rice: 0.3 billion US dollars) to improve the farmland infrastructure in the areas where the $\mathrm{N}$ output below $80 \mathrm{~kg} \mathrm{ha}^{-1}$ (Fig. 5 and Supplementary Table 6).

The optimization of fertilization practices (best $\mathrm{N}$ management) can increase the yield of wheat, maize and rice by $2 \%, 6 \%$ and $1 \%$ while simultaneously reducing the $\mathrm{N}$ application rate by $4 \%, 12 \%$ and $5 \%$, respectively, considering an optimal N application rate with farmers' practices (Fig. 4 and Supplementary Table 1). The optimization of the fertilization practices have a significant effect in maize producing areas, with an increase of NUE by $12 \%$, and a reduction of the $\mathrm{N}$ surplus by $31 \%$ (Supplementary Fig. 1 illustrates the spatial distribution of $\mathrm{N}$ application rates, yield, NUE and $\mathrm{N}$ surplus after optimizing fertilization practices). Economic benefits arising from fertilizer cost savings and yield increases can increase revenues by up to 5.2 billion US dollars as a consequence of optimizing fertilization practices. At the same time, these managements reduce the $\mathrm{N}$ surplus by $1.7 \mathrm{Tg} \mathrm{N}$ (see Fig. 5 and Supplementary Table 2). This means that optimizing $\mathrm{N}$ fertilizer use could produce more yield with less pollution.

\section{Methods}

\section{On-farm fertilization experiments}

Data for a total of 35,502 sites were collected from field trials over the period 2005 to 2015 for main food crops ( $n=10,583$ for wheat, 15,042 for maize and 9,877 for rice), with sites spread across all agroecological zones in China (Fig. 1). This experiment was designed by the Ministry of Agriculture and Rural Affairs of China to determine the optimal rate of fertilization, which included 3 factors (N, P, K), 4 levels and 14 treatments without replication. In this study, four treatments were selected to calculate the optimal $\mathrm{N}$ application rate (RN) of the three crops: (1) no $\mathrm{N}$ fertilizer treatment ( $\left.\mathrm{N}_{0}\right)$; (2) low $\mathrm{N}$ fertilizer treatment $\left(\mathrm{N}_{1}\right)$; (3) Medium $\mathrm{N}$ fertilizer treatment $\left(\mathrm{N}_{2}\right)$; (4) high $\mathrm{N}$ fertilizer treatment $\left(\mathrm{N}_{3}\right)$. The $\mathrm{N}_{2}$ rate was determined by local agricultural extension employees $($ Staff of the Local Agriculture Bureau and Agricultural Technology Centre that have been uniformly trained) according to their experience and target yield (1.1 times the average yield of the past 5 years), and the rates of $N_{1}$ and $N_{3}$ were $50 \% N_{2}$ and $150 \% N_{2}$, respectively. The average $N_{2}$ rates of wheat, maize and rice were 185 , 190 and $164 \mathrm{~kg} \mathrm{ha}^{-1}$, respectively. Approximately one-third of granular urea was applied at sowing, while the remainder was applied as a topdressing. The rates of $\mathrm{P}$ and $\mathrm{K}$ fertilizer in each treatment were about $90 \mathrm{~kg} \mathrm{ha}^{-1}$, which were applied by broadcasting before sowing. None of these experiments had inputs of animal manure or other organic $\mathrm{N}$ sources.

Individual plots were approximately $40 \mathrm{~m}^{2}$ in size. The management of all experiments, including variety, planting, harvesting, weed and pest control, was undertaken by local farmers according to their experience and based on instructions provided by local agricultural extension employees in a field manual. Upon harvest, a $2.5 \mathrm{~m} \times 8 \mathrm{~m}$ section was harvested from each experimental plot to measure yield. Grain yield weight of wheat, maize and rice was adjusted to a moisture content of $14 \%, 15.5 \%$ and $14 \%$, respectively, and was displayed for all regions in Supplementary Fig. 2 .

Page 3/10 
For each treatment plot, soil properties were examined prior to starting the experiments, and values were determined based on soil samples from a combined sample of 10-20 cores from depths of 0-20 cm. Five stover and grain samples were collected and analyzed separately after harvest. Soil samples were dried and sieved for determining soil organic $\mathrm{C}$ content by vitriol acid-potassium dichromate oxidation ${ }^{37}$; representative subsamples were taken to determine $\mathrm{pH}$ (1:1 w/v soil/water); total $\mathrm{N}$ was determined by the method described by Black ${ }^{38}$; available $\mathrm{N}$ (alkaline hydrolyzable) was measured following the procedures described by $\mathrm{Lu}^{39}$; available $\mathrm{P}$ was determined by the Olsen $\mathrm{P}$ method described by Olsen et al. ${ }^{40}$ and available $\mathrm{K}$ by the method of Shi ${ }^{41}$. To determine the $\mathrm{N}$ content, the stover and grain samples were digested with $\mathrm{H}_{2} \mathrm{SO}_{4}-\mathrm{H}_{2} \mathrm{O}_{2}$ separately, and the concentrations of total $\mathrm{N}$ in the digesting solution were measured using the micro-Kjeldahl method ${ }^{42}$. Three subsamples were analyzed for each sample and average values were reported. The climatic data for each experiment site were derived from local weather stations. The data of soil nutrient and climate for each region are shown in Supplementary Fig. 3 and Supplementary Fig. 4, respectively.

\section{Regional distribution of main food crops in China}

In this study, on-farm $\mathrm{N}$ fertilizer experiments covered 31 provinces and included three grain crops. Based on climate types and planting systems, cropland of China was subdivided into seven principal regions ${ }^{43}$, each comprising several provinces, i.e., Northeast region (NE), North China Plain region (NCP), Middle and lower Yangtze River region (MLYR), Southeast region (SE), Southwest region (SW), Northwest region (NW) and others (Supplementary Fig. 5 shows the detailed subregion and crop distribution). For regions summarized under 'others' there were no data available and so these regions were not included in the present study, i.e., Taiwan, Hong Kong and Macao.

\section{Estimation of optimal $\mathrm{N}$ application rate}

In this study, the optimal $\mathrm{N}$ application rate was calculated to obtain maximum economic benefits. First, a quadratic regression model was used to assess the grain yield response to $\mathrm{N}$ application rate for the 35,502 on-farm N fertilizer experiments using RStudio software (version 3.5.3; RStudio Inc. 2011), showing that yield significantly responded to the $N$ rate $(P<0.05)^{44}$. Next, the following variables were calculated at different $N$ rate: the yield increase (amount above the yield in the $\mathrm{N}_{0}$ treatment), gross return for the yield increase (yield increase times grain price), cost of $\mathrm{N}$ fertilizer ( $\mathrm{N}$ rate times fertilizer price), and the net return on $\mathrm{N}$ application (gross return minus fertilizer cost). Finally, the average net return for each $\mathrm{N}$ increment across all $\mathrm{N}$ response curves was calculated. The $\mathrm{N}$ application rate with the largest average net economic return was defined as the optimal $\mathrm{N}$ application rate ${ }^{45}$. In this study, we calculated the optimal $\mathrm{N}$ application rate and the corresponding yield, NUE and N surplus based on county (Fig. 2) and regional (Supplementary Fig. 6) scales. The N fertilizer price and market prices of cereal were determined according to the reported by the Ministry of Agriculture and Rural Affairs of the People's Republic of China in 20182020: the average price of $\mathrm{N}$ fertilizer was $\$ 0.67 \mathrm{~kg}^{-1} \mathrm{~N}$, and the mean price of wheat, maize and rice grain were $\$ 0.18,0.15$ and $0.21 \mathrm{~kg}^{-1}$, respectively 4 .

\section{Nitrogen use efficiency (NUE) and nitrogen surplus $\left(\mathrm{N}_{\text {sur }}\right)$}

Nitrogen use efficiency and $\mathrm{N}_{\text {sur }}$ are important for assessing $\mathrm{N}$ management. In this study, the NUE concept focused on the efficiency of all $\mathrm{N}$ inputs and represents the efficiency of all $\mathrm{N}$ inputs transferring to harvested crop $\mathrm{N}$ content. $\mathrm{N}_{\text {sur }}$ was used to evaluate the balance of $\mathrm{N}$ input and output. The main external $\mathrm{N}$ input included the following sources: chemical fertilizer, atmospheric deposition, biological $\mathrm{N}$ fixation. Minor $\mathrm{N}$ inputs (e.g., from irrigation and seed) were not accounted for. The $\mathrm{N}$ output includes the $\mathrm{N}$ harvested in cereal grain without considering straw, because of the governmental ban on straw burning and economic incentives to return straw since $2000^{47,48}$. We assumed accordingly that all straw was returned to the field (straw $\mathrm{N}$ output was offset by straw $\mathrm{N}$ input). Nitrogen use efficiency and $\mathrm{N}_{\text {sur }}$ are calculated as

$\mathrm{NUE}=\mathrm{N}_{\mathrm{har}} /\left(\mathrm{N}_{\mathrm{fer}}+\mathrm{N}_{\mathrm{dep}}+\mathrm{N}_{\mathrm{fix}}\right) \times 100 \%$

$\mathrm{N}_{\text {sur }}=\mathrm{N}_{\text {fer }}+\mathrm{N}_{\text {dep }}+\mathrm{N}_{\text {fix }}-\mathrm{N}_{\text {har }}$

where $\mathrm{N}_{\text {har }}$ is the $\mathrm{N}$ output by harvested in cereal grain, $\mathrm{N}_{\text {fer }}, \mathrm{N}_{\text {dep }}$ and $\mathrm{N}_{\mathrm{fix}}$ are the $\mathrm{N}$ input by chemical fertilizer, atmospheric deposition, biological $\mathrm{N}$ fixation, respectively.

The $\mathrm{N}$ input from atmospheric deposition is obtained from the seasonal average $\mathrm{N}$ deposition summarized by Xu et al. ${ }^{49}$ comprising data from 27 rural sites covered by the National Nitrogen Deposition Monitoring Network (NNDMN). There are 2-8 monitoring sites in each region of this study according to the data in NNDMN. Regional N deposition rates were determined as the average of measurements at all sites in each region, and $\mathrm{N}$ deposition rates on specific crops per growth season were estimated according to the planting and harvest period of the crops. Nitrogen input from biological $\mathrm{N}$ fixation was obtained from Bouwman et al. ${ }^{50}$ : the $\mathrm{N}$ fixation rate associated with rice production was set to be $25 \mathrm{~kg} \mathrm{~N}^{-1}$, and $5 \mathrm{~kg} \mathrm{~N}^{-1}$ for wheat and maize. The average $\mathrm{N}$ input for each region is shown in Supplementary Table 7.

We calculated the grain $\mathrm{N}$ harvest by grain yield and grain $\mathrm{N}$ concentration (if experiments did not determine grain $\mathrm{N}$ concentration, the value of $\mathrm{N}$ content is derived from Ti et al. ${ }^{51}$, at $2.3 \%, 1.4 \%$ and $1.9 \%$ of grain $\mathrm{N}$ content for wheat, maize and rice, respectively):

$\mathrm{N}_{\text {har }}=$ grain yield $\times$ grain $\mathrm{N}$ concentration

\section{Evaluation system}

The EU Nitrogen Expert Panel ${ }^{27}$ proposed an evaluation system for evaluating farmland $\mathrm{N}$ management by comprehensively considering $\mathrm{N}$ input and output, the NUE, and an N surplus index in a cropping system. Experts believe that the best $\mathrm{N}$ management can be achieved with values of $\mathrm{N}$ output $\geq 80$ kg ha ${ }^{-1}, 50 \%$ $\leq \mathrm{NUE} \leq 90 \%, \mathrm{~N}$ surplus $\leq 80 \mathrm{~kg} \mathrm{ha}^{-1}$. When the NUE is too high (NUE > 90\%), there is a risk of soil consumption mining, and if NUE is too low (NUE < $50 \%$ ), 
there is a risk of substantial $\mathrm{N}$ losses to the environment and hence pollution. The minimum $\mathrm{N}$ output $\left(80 \mathrm{~kg} \mathrm{ha}^{-1}\right)$ is set to meet the minimum production level, the maximum $\mathrm{N}$ surplus is limited $\left(80 \mathrm{~kg} \mathrm{ha}^{-1}\right)$ to avoid substantial $\mathrm{N}$ losses. We referred to this evaluation system to evaluate whether the optimal $\mathrm{N}$ application rate can meet the best $\mathrm{N}$ management.

\section{Economic and environmental benefits}

In this study, the economic benefits include two main elements: (1) benefit of cost saving from reduced N fertilizer application; (2) benefit of increasing yield. The environmental benefits were expressed by the reduction of $\mathrm{N}$ surplus. The benefits of optimizing $\mathrm{N}$ application were estimated by comparing with farmers' conventional fertilizer application practices in China. The overall benefits of the optimization of management practices were estimated by comparing with optimal $\mathrm{N}$ application rates. Data on farmers' conventional fertilizer application rates/practices were derived from published literature ${ }^{52}$ (Supplementary Table 1). Economic benefits were derived by multiplying $N$ reduction (yield increase) per unit area by the price of fertilizer $N$ (grain) and by the planting area of the crop, in which the planting area of wheat, maize and rice were $2.4,4.1$ and $3.0 \times 10^{6}$ ha $^{-1}$, respectively (see Supplementary Table 2 for more details) ${ }^{53}$. Different optimization strategies were applied to regions which can not meet all requirements for best $\mathrm{N}$ management practices under optimization of $\mathrm{N}$ application $^{54,55}$ (Supplementary Fig. 7 and Supplementary Table 3,4,5,6 showed the specific optimization measures and implementation costs associated).

\section{Declarations}

\section{Data availability}

Data supporting the findings of this study beyond those found in the Supplementary Information are available from the corresponding author upon reasonable request.

\section{Acknowledgments}

This study was supported by the National Key Research and Development Project of China (2016YFD0200301, 2018YFC0213300), and National Natural Science Foundation of China (41822701, 41773068, 4201101080 and 42077098). The work contributes to the "Towards International Nitrogen Management System (INMS)" funded by the United Nations Environment Programme (UNEP, GEF Project ID: 5400-01142).

\section{Author contributions}

Y.D. and B.G. designed the study, K.R., M.X. and Y.D. conducted the research, K.R. and B.G. wrote the first draft, S.R. revised the paper, R.L., L.Z., S.L., H.W. and H.G. collected the data, and all authors contributed to the paper writing, discussion, and revision.

\section{Competing interests}

The authors declare no competing interests.

\section{Additional information}

Supplementary information is available for this paper.

\section{References}

1. Tilman, D., Cassman, K. G., Matson, P. A., Naylor, R. \& Polasky, S. Agricultural sustainability and intensive production practices. Nature 418, $671-677$ (2002).

2. Godfray, H. C. J. et al. Food security: the challenge of feeding 9 billion people. Science 327, 812-818 (2010).

3. Tilman, D., Balzer, C., Hill, J. \& Befort, B. L. Global food demand and the sustainable intensification of agriculture. Proc. Natl Acad. Sci. USA 108, 2026020264 (2011).

4. Food: The growing problem. Nature 466, 546-547 (2010).

5. Samberg, L., Gerber, J., Ramankutty, N., Herrero, M., \& West, P. Subnational distribution of average farm size and smallholder contributions to global food production. Environ. Res. Lett. 11, 124010 (2016).

6. Ju, X., Gu, B., Wu, Y., \& Galloway, J. Reducing China's fertilizer use by increasing farm size. Glob. Environ. Change 41, 26-32 (2016).

7. Cui, Z., Zhang, F., Chen, X., Dou, Z., \& Li, J. In-season nitrogen management strategy for winter wheat: Maximizing yields, minimizing environmental impact in an over-fertilization context. F. Crop. Res. 116, 140-146 (2010).

8. Global "4R" nutrient stewardship framework: Developing fertilizer best management practices for delivering economic, social and environmental benefits (International Fertilizer Association, 2009);

http://www.ipni.net/ipniweb/portal/4r.nsf/0/BAB4157B488871A385257DF100739D94/\$FILE/The\%20Global\%204R\%20Nutrient\%20Stewardship\%20Frar

9. Sanchez, P. A. En route to plentiful food production in Africa. Nat. Plants 1, 14014 (2015).

10. Larson, C. Losing arable land, China faces stark choice: adapt or go hungry. Science 339, 644-645 (2013).

11. I West, P. C. et al. Leverage points for improving global food security and the environment. Science 345, 325-328 (2014).

12. Gu, B., Ge, Y., Chang, S., Luo, W., \& Chang, J. Nitrate in groundwater of china: sources and driving forces. Glob. Environ. Change 23, 1112-1121 (2013).

13. Guo, J. et al. Significant acidification in major Chinese croplands. Science 327, 1008-1010 (2010). 
14. Zhang, W. et al. New technologies reduce greenhouse gas emissions from nitrogenous fertilizer in China. Proc. Natl Acad. Sci. USA 110, 8375-8380 (2013).

15. Ti, C. et al. Dry deposition of $\mathrm{N}$ has a major impact on surface water quality in the Taihu Lake region in southeast China. Atmos. Environ. 190, 1-9 (2018). 16. Zhang, W. et al. Closing yield gaps in China by empowering smallholder farmers. Nature 537, 671-674 (2016).

17. Wu, Y. et al. Policy distortions, farm size, and the overuse of agricultural chemicals in China. Proc. Natl Acad. Sci. USA 115, 7010-7015 (2018).

18. Ren, C. et al. The impact of farm size on agricultural sustainability. J. Clean. Prod. 220, 357-367 (2019).

19. Yang, X. et al. Optimising nitrogen fertilisation: A key to improving nitrogen-use efficiency and minimising nitrate leaching losses in an intensive wheat/maize rotation (2008-2014). F. Crop. Res. 206, 1-10 (2017).

20. Che, S. et al. Review grain yield and nitrogen use efficiency in rice production regions in China. J. Integr. Agric. 14, 2456-2466 (2015).

21. Cassman, K. G., Dobermann, A., Walters, D. T. \& Yang, H. Meeting cereal demand while protecting natural resources and improving environmental quality. Annu. Rev. Environ. Resour. 28, 315-358 (2003).

22. Li, T. et al. Region-specific nitrogen management indexes for sustainable cereal production in China. Environ. Res. Commun. 2, 075002 (2020).

23. Van Grinsven, H. J. M. et al. Management, regulation and environmental impacts of nitrogen fertilization in northwestern Europe under the Nitrates Directive; A benchmark study. Biogeosciences 9, 5143-5160 (2012).

24. Cui, Z. et al. Pursuing sustainable productivity with millions of smallholder farmers. Nature 555, 363-366 (2018).

25. Chen, X. et al. Integrated soil-crop system management for food security. Proc. Natl Acad. Sci. USA 108, 6399-6404 (2011).

26. Liu, S. et al. Importance of matching soil N transformations, crop N form preference, and climate to enhance crop yield and reducing $\mathrm{N}$ loss. Sci. Total Environ. 657, 1265-1273 (2019).

27. EU Nitrogen Expert Panel. Nitrogen Use Efficiency (NUE)-An Indicator for the Utilization of Nitrogen in Agriculture and Food Systems (Wageningen Univ. Press, 2015).

28. Duan, Y. et al. Nitrogen use efficiency in a wheat-corn cropping system from 15 years of manure and fertilizer applications. F. Crop. Res. 157, 47-56 (2014).

29. Xia, L., Lam, S. K., Yan, X., \& Chen, D. How does recycling of livestock manure in agroecosystems affect crop productivity, reactive nitrogen losses, and soil carbon balance? Environ. Sci. Technol. 51, 7450-7457 (2017).

30. Xia, L. et al. Can knowledge-based N management produce more staple grain with lower greenhouse gas emission and reactive nitrogen pollution? A meta-analysis. Glob. Change Biol. 23, 1917-1925 (2017).

31. Li, T. et al. Enhanced-efficiency fertilizers are not a panacea for resolving the nitrogen problem. Glob. Change Biol. 24, 511-521 (2018).

32. Wei, S., Wang, X., Zhu, Q., Jiang, D. \& Dong, S. Optimising yield and resource utilisation of summer maize under the conditions of increasing density and reducing nitrogen fertilization. Sci. Nat. 104, 2-11 (2015).

33. Shi, Q., Wang, H., Chen, F. \& Chu, Q. The spatial-temporal distribution characteristics and yield potential of medium-low yielded farmland in China (in Chinese). Chin. Agric. Sci. Bull. 26, 369-373 (2010).

34. Chen, Y. et al. The quality analysis of cultivated land in China (in Chinese). Sci. Agric. Sin. 44, 3557-3564 (2011).

35. Xu, M., Lu, C., Zhang, W., Li, L. \& Duan, Y. Situation of the quality of arable land in China and improvement strategy (in Chinese). Chin. J. Agric. Resour. Reg. Plan. 37, 8-14 (2016).

36. 5.33 million hectares of high-standard farmland will be completed on schedule in 2020 (in Chinese) (Ministry of Agriculture and Rural Affairs of China, 2020); http://www.moa.gov.cn/xw/zwdt/202012/t20201216_6358284.htm

37. Walkley, A. \& Black, I. A. An examination of the degtjareff method for determining soil organic matter, and a proposed modification of the chromic acid titration method. Soil Sci. 37, 29-38 (1934).

38. Black C. A. Methods of soil analysis. Part 2. Agron. Monogr. 9. (American Standards Association Press, Madison, WI., 1965)

39. Lu, R. Analytical methods of soil agricultural chemistry (in Chinese) (China Agricultural Science and Technology Press, Beijing, 2000)

40. Olsen, S., Cole, C., Watanabe, F. \& Dean, A. Estimation of available phosphorus in soils by extraction with sodium bicarbonate. (U.S.D.A. Circ. 939. U.S. Gov. Press, Washington, 1954)

41. Shi, R. Soil and agricultural chemistry analysis (in Chinese) (China Agriculture Press, Beijing, 1976)

42. Page, A. L. et al. Methods of soil analysis. Part 2. Agron. Monogr. 9. (A.S.A. and S.S.S.A. Press, Madison, WI, 1982)

43. Zhang, C., Ju, X., Powlson, D., Oenema, O. \& Smith, P. Nitrogen surplus benchmarks for controlling N pollution in the main cropping systems of China. Environ. Sci. Technol. 53, 6678-6687 (2019).

44. Wallach, D. \& Loisel, P. Effect of parameter estimation on fertilizer optimization. Appl. Stat. 43, 641 (1994).

45. Stehfest, E. \& Bouwman, L. $\mathrm{N}_{2} \mathrm{O}$ and $\mathrm{NO}$ emission from agricultural fields and soils under natural vegetation: Summarizing available measurement data and modeling of global annual emissions. Nutr. Cycl. Agroecosyst. 74, 207-228 (2006).

46. National Data: Online Statistical Service (Ministry of Agriculture and Rural Affairs of China, 2020); http://zdscxx.moa.gov.cn:8080/nyb/pc/sourceArea.jsp

47. Han, D. et al. Large soil organic carbon increase due to improved agronomic management in the North China Plain from 1980 s to 2010 s. Glob. Chang. Biol. 24, 987-1000 (2018).

48. Zhao, Y. et al. Economics- and policy-driven organic carbon input enhancement dominates soil organic carbon accumulation in Chinese croplands. Proc. Natl Acad. Sci. USA 115, 4045-4050 (2018). 
49. Xu, W. et al. Quantifying atmospheric nitrogen deposition through a nationwide monitoring network across China. Atmos. Chem. Phys. Discuss. 15, 18365-18405 (2015).

50. Bouwman, L. et al. Exploring global changes in nitrogen and phosphorus cycles in agriculture induced by livestock production over the $1900-2050$ period. Proc. Natl Acad. Sci. USA 110, 20882-20887 (2013).

51. Ti, C., Pan, J., Xia, Y. \& Yan, X. A nitrogen budget of mainland China with spatial and temporal variation. Biogeochemistry 108, 381-394 (2012).

52. Wu, L. et al. Nitrogen fertilizer input and nitrogen use efficiency in Chinese farmland (in Chinese). China Soils Fert. 4, 76-83 (2016).

53. National Data: Online Statistical Service (National Bureau of Statistics of the People's Republic of China, 2020);

http://www.stats.gov.cn/tjsj/ndsj/2020/indexch.htm

54. Shen, R., Chao, W. \& Sun, B. Soil related scientific and technological problems in implementing strategy of "storing grain in land and technology" (in Chinese). Bull. Chin. Acad. Sci. 33, 135-144 (2018).

55. Fu, H., Li, T., Cao, H. \& Zhang, W. Research on the driving factors of fertilizer reduction in China (in Chinese). Plant Nutr. Fertil. Sci. 26, 561-580 (2020).

\section{Figures}
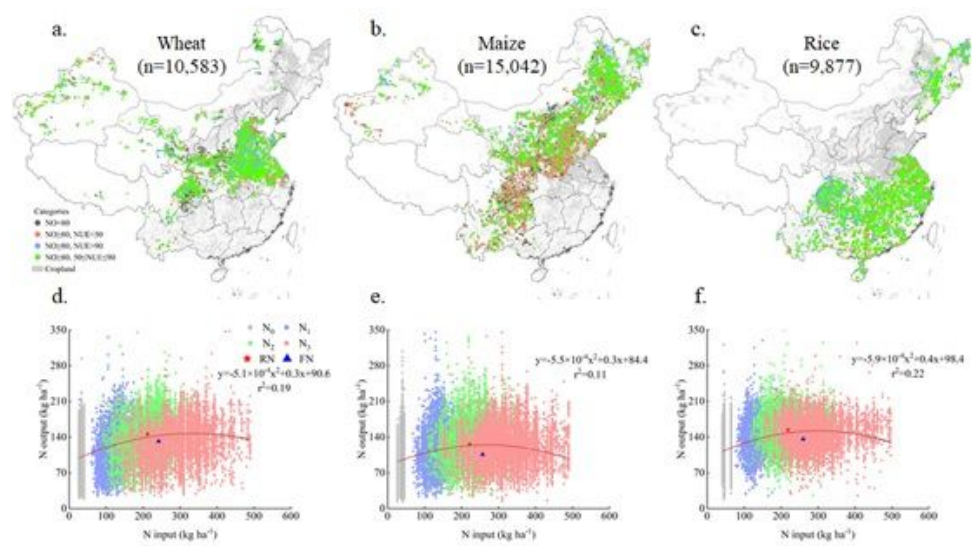

\section{Figure 1}

Distribution of fertilization experiments and yield response curves. (a)-(c) regional experimental site distribution of wheat, maize, and rice, respectively; $\mathrm{n}$ indicates experimental sites number; NO: nitrogen output (unit: kg ha-1); NUE: nitrogen use efficiency (unit: \%). (d) -(f) N yield response to N input for wheat, maize, and rice, respectively. Red squares in (d)-(f) represent optimal N rates (RN); Blue triangles in (d) - (f) represent farmers' conventional fertilizer application rates (FN). Note: The designations employed and the presentation of the material on this map do not imply the expression of any opinion whatsoever on the part of Research Square concerning the legal status of any country, territory, city or area or of its authorities, or concerning the delimitation of its frontiers or boundaries. This map has been provided by the authors. 

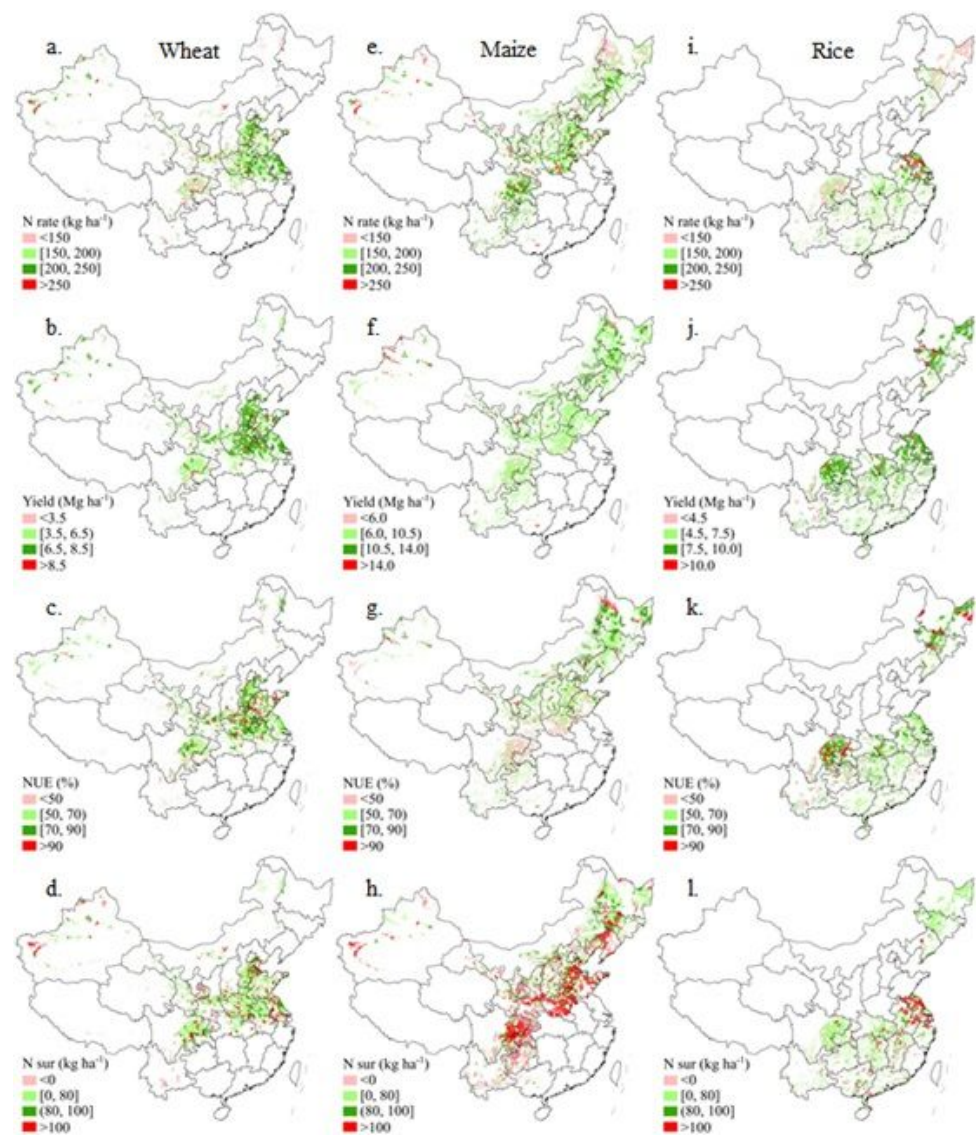

Figure 2

Optimal $\mathrm{N}$ application rate ( $\mathrm{N}$ rate) and corresponding yield, nitrogen use efficiency (NUE) and nitrogen surplus (Nsur) of three grain crops) for wheat (a-d), maize $(\mathrm{e}-\mathrm{h})$, and rice $(\mathrm{i}-\mathrm{l})$. Note: The designations employed and the presentation of the material on this map do not imply the expression of any opinion whatsoever on the part of Research Square concerning the legal status of any country, territory, city or area or of its authorities, or concerning the delimitation of its frontiers or boundaries. This map has been provided by the authors. 
a.

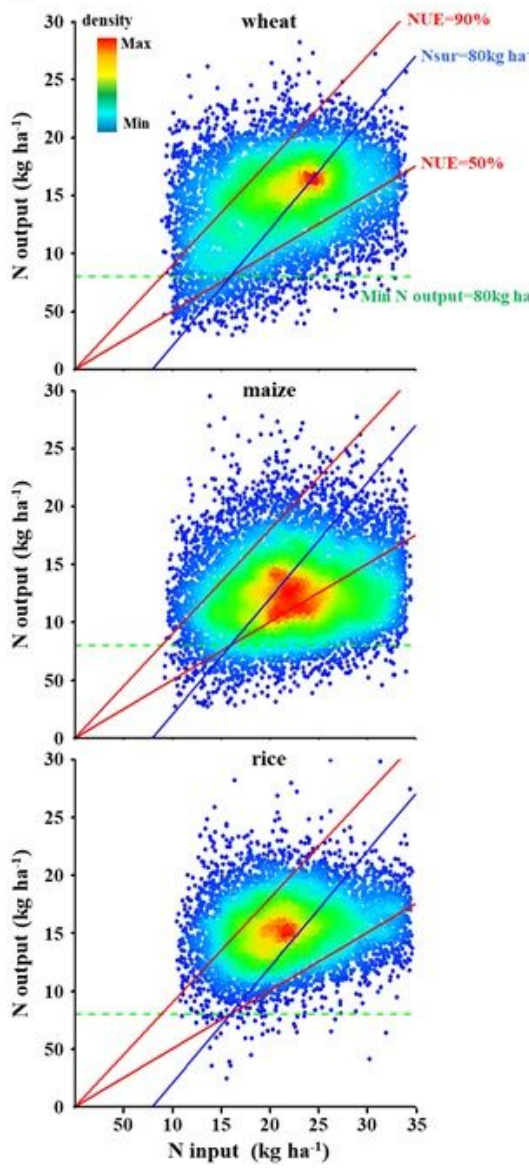

b.
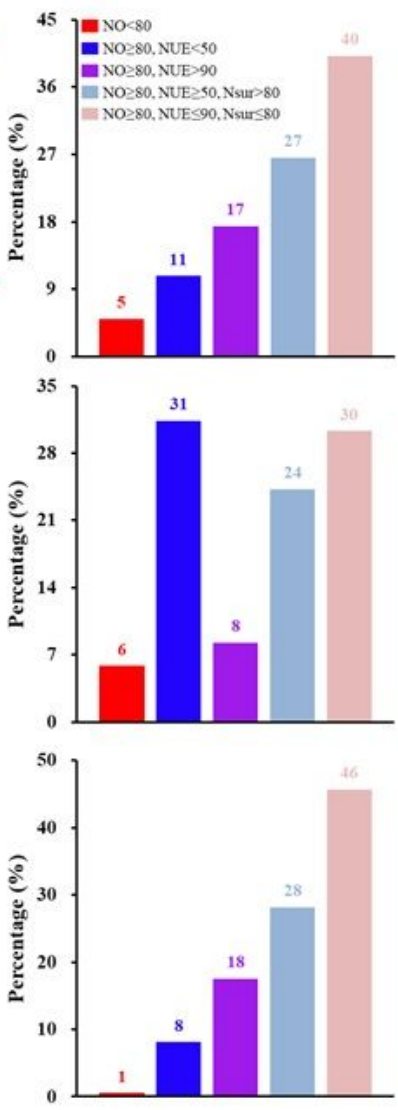

\section{Figure 3}

Response of $\mathrm{N}$ output to N input under optimal N application rate. NO: nitrogen output (unit: kg ha-1); NUE: nitrogen use efficiency (unit: \%); Nsur: nitrogen surplus (unit: $\mathrm{kg} \mathrm{ha-1).} \mathrm{Color} \mathrm{of} \mathrm{the} \mathrm{dots} \mathrm{represent} \mathrm{the} \mathrm{density} \mathrm{of} \mathrm{dots.} \mathrm{Numbers} \mathrm{on} \mathrm{the} \mathrm{top} \mathrm{of} \mathrm{the} \mathrm{bars} \mathrm{(b)} \mathrm{refer} \mathrm{to} \mathrm{the} \mathrm{percentage} \mathrm{of} \mathrm{sites} \mathrm{in} \mathrm{each} \mathrm{quadrant} \mathrm{(a)}$ to all sites in each crop (wheat: 10,583, maize: 15,042, rice: 9,877).
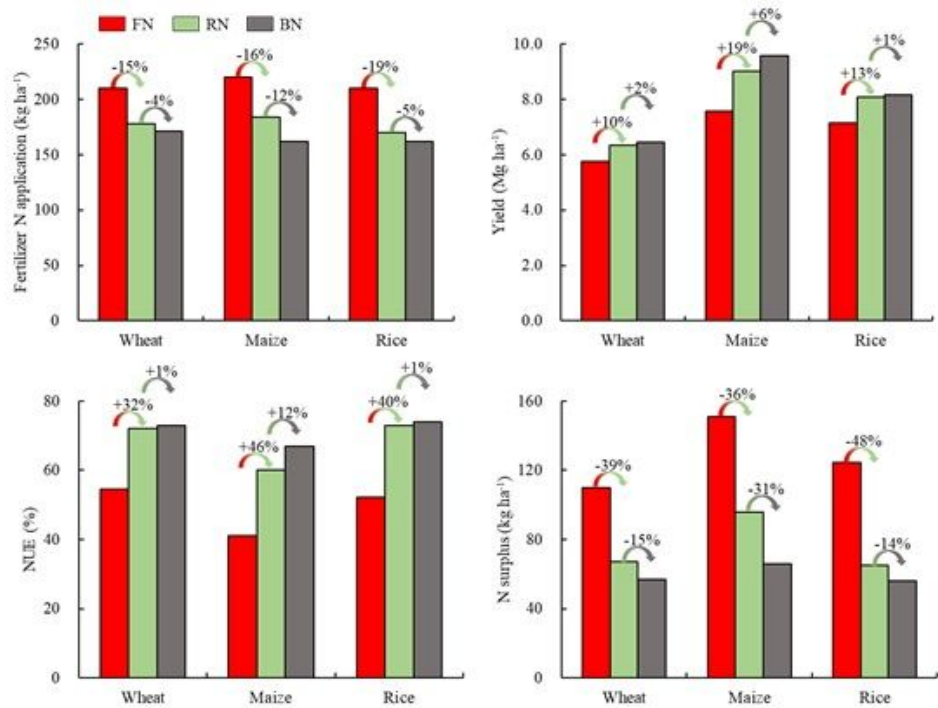

Figure 4

Potential for reduction of nitrogen fertilizer and improvement of nitrogen use efficiency under optimal $\mathrm{N}$ rate (RN) and best $\mathrm{N}$ management (BN), compared with that under farmers' conventional $\mathrm{N}$ application rate (FN). 


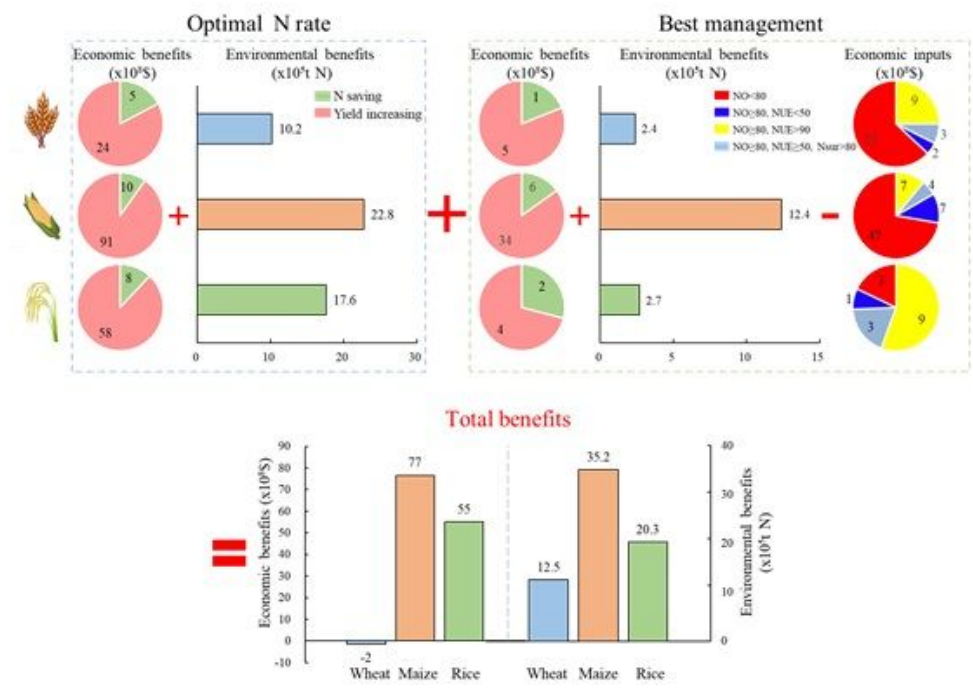

\section{Figure 5}

Economic and environmental benefits under optimal N rate and best management. NO: nitrogen output (unit: kg ha-1); NUE: nitrogen use efficiency (unit: \%); Nsur: nitrogen surplus (unit: kg ha-1).

\section{Supplementary Files}

This is a list of supplementary files associated with this preprint. Click to download.

- Supplementaryinformation.pdf 